\title{
Correlates of Job Satisfaction Among Civil Servants Close to Retirement in Lagos State
}

\author{
Adedoyin-Alao Olusola \\ University of Lagos, Department of Business Administration, NIGERIA
}

Ajibola Abdulrahamon Ishola

University of Ibadan, Department of Psychology, NIGERIA

Received 21 February 2019 • Revised 27 May 2019 • Accepted 30 June 2019

\section{Abstract}

Job satisfaction is important as it informs the Human Resource department whether work is still meaningful at pre-retirement stage. Career transition variables promoting positive job-related attitude have not been appraised in available literature. This study perused the relationships between job satisfaction and career transition variables among civil servants nearing retirement in Lagos state. The study was a quantitative study which utilized the cross-sectional survey strategy to collect the data. One hundred and seventy-five (175) employees from selected ministries were sampled through a multi-stage sampling method. The research instrument was a self-report questionnaire and method of data analysis includes descriptive statistics and PPMC correlation analysis tested at $\mathrm{p} \leq \mathrm{0.05}$. Career transition readiness, self-esteem, and self-efficacy relate to elevated job satisfaction. In addition, career support, control and decision correlated with low job satisfaction. Ultimately, the study demonstrated that being confident and preparedness for future roles increases job satisfaction at twilight of civil servants' career. The implications for employees close to retirement were discussed.

Keywords: job satisfaction, career transition readiness, self-efficacy, self-esteem, Lagos State public service.

\section{Introduction}

Nowadays organizations are compelled to handle two connected challenges: maintaining actively performing personnel and, increasing employees' well-being and job satisfaction beneath conditions of increase of job demand, in age diverse population (Guglielmi et al., 2016). It is instructive that being close to retirement influences employees' perceptions and evaluation of their job, distinctive desires, values and expectations that they think are vital to them (Drabe, Hauff \& Richter, 2014; Guglielmi et al., 2016). A key side of personnel management is developing an understanding of way to inspire and satisfy older workers, since extremely glad workers show lower turnover intentions, lower absence rates and infrequently higher performance that optimizes organisations' success (Drabe et al., 2014).

Job satisfaction is outlined as "the extent to which individuals like (satisfaction) or dislike (dissatisfaction) their jobs”. It results from individuals' perception and analysis of their job,

(C) Authors. Terms and conditions of Creative Commons Attribution 4.0 International (CC BY 4.0) apply. Correspondence: Ajibola Abdulrahamon Ishola, University of Ibadan, Department of Psychology, NIGERIA. E-mail: ajibola ishola@yahoo.co.uk. 
influenced by their own distinctive desires, values and expectations they think are vital to them. Job satisfaction is outlined as "the extent of affectation about ones' job in terms of like (satisfaction) or dislike (dissatisfaction)" (Guglielmi et al., 2016). The interest in job satisfaction stems from its major impact on employees' outcome, long-term work success and it is direct link to an individual's happiness (Mukhtar, 2012). Being satisfied with work is one important indicators of wellness of employees close to retirement.Employees close to retirement are presumed to be more satisfied with their jobs only if their job-related attitude and disposition continues to improve. Determinant of job satisfaction close to retirement are of special interest to experts as the employees' perceptions, evaluations, convictions and sentiments about both their job and retiring from the profession is probably going to impact their retirement practices. Prior studies inform that high job satisfaction is suggested to be a valuable psychological resource which informs individuals attachment to the organization and do not want to relinquish at retirement (Davies, Van der Heijden \& Flynn, 2017). However, prevailing levels of job satisfaction at preretirement has been linked to how employees react to how they are being treated at work. In this trend, the way employees perceived their gradual disengagement by management may have play a significant role whether employees are still happy close to retirement. Career transitions have been implicated as a major albatross in employees close to retirement job satisfaction (Robertson, 2010).

Career transition, a behavioural predisposition to engage in proactive strategies to make successfully role changes inherent towards a person's career in the present job (Robertson, 2010). Career transition is broken down into five dimensions. These are psychological resources believed potentiates which improve older employees job satisfaction. These factors include readiness, efficacy, control, perceived social support, and decision independence (Robertson, 2010). Career readiness, suggests individuals perceived readiness to move into another job after retirement or entrepreneurial activities. Career readiness plays a crucial role towards retirement as energise and direct career and work behaviour towards retirement (Robertson, 2010). Career confidence, reflects how much confident about to retire person feels towards carrying out activities necessary to make a successful retirement i.e. entrepreneurship training, sabbatical leave learning new skills etc. A key factors in career development pursuits on what to do after retirement (Robertson, 2010). The third dimension is the perception the about is in "control" of retirement plans transitions. The belief that individuals have the skills and knowledge required to handle the change associated with career transitions (Robertson, 2010). Another factor is that influence about to retire is having the necessary career social support from their organisation. These include provisions of training and organisational support in taking up opportunities and exposure that will lead to self-sufficiency in later life for example taking political appointments, study leave, entrepreneurship etc. Lastly, about to retire "decision independence", the perception that the career transition decision is an independent or autonomous one, or a decision made in consideration of the needs of others (Heppner et al., 1994).

Aside organisational prescribed, dispositional factors play significant role in job related attitude for ageing employees. Variables affecting job satisfaction includes the "selfconcept" or "self belief" of the employees close to retirement place on themselves. The duo of selfefficacy and self-esteem has been linked to job satisfaction outcome in several studies (Mega et al., 2018). Self-concept, inspires evaluations and assessment that shaped the prevailing levels of job related attitude in employees; positive evaluations leads to positive feelings and negative evaluations the contrary (Ibid., 2018). Self-esteem translates to the perception of self-worth that suggests how much the employees' values their achievement in life and present contribution to the organisation. Self-efficacy the second self-concept variable is the individual belief in their own ability and confidence to see through all endeavours in life. Ivancevich et al. (2006) relates that self-efficacy to personal beliefs about competence and self-ability. In actual sense it refers to the feeling of confidence derived over time through handling of organisational activities and belief that one can handle any future events or tasks confidently (Mega et. al., 2018). 
In the Nigeria public service paid less attention to its employees at the twilight of their careers compared to employees in the private sector. Less attention is paid to activities that stimulates high job morale such that job satisfaction is hampered as such, employees close to retirement are disgruntled loosing interest in their jobs. Against this backdrop, this study seeks to investigate psycho-social correlates of job satisfaction among pre-retirement employees among civil servant in Lagos State, Nigeria. The following research questions will be answered in this study:

(1) Examined if career transitions readiness, efficacy, control, perceived social support, and decision independence variables were significant correlates of job satisfaction.

(2) The relationship between self-esteem, self-efficacy and job satisfaction.

(3) Assessed if self-esteem, self-efficacy will moderate the role of readiness, efficacy, control, perceived social support, and decision independence variables as predictors of job satisfaction.

\subsection{Theoretical framework}

Locke's (1976) range of affect theory and supers career construction theory guided this study. Range of affect theory proposed that job satisfaction translates to differences observe in what an individual wants in a job and his or her actual experience aftermath. The theory posit that if individuals values a certain facet of their job whether they experience satisfaction on the job depends on whether valued expectation are met or not compared to somebody who did not appreciate the value. Workers know what they want in a job and when they don't get it, they become stressed and dissatisfaction sets in. At career twilight more employees look out for what they stand to gain as they leave the organisation and what value they are leaving behind to be remember for. For most people in the public service experience job dissatisfaction due unplanned career changes, corruption, poor remuneration, low morale makes retirement decision difficult thus their level of dissatisfaction. Apart from corruption, poor career progression creates a stressful environment for employees. Career construction theory, proposed that individuals build their career by given meaning to their own work behaviour. Career construction theory goes through intuitive thinking through which individuals give interpretation and direction on their vocational behaviour.

Career construction theory views adaptation to career at twilight is shaped by five cardinal behaviours: exploration, orientation, management, disengagement and establishment. These positive activities form a cycle of adjustment constantly repeated as new transitions seem at the horizon. As each transition emanates, individuals can adapt more successfully if they meet the exchange with focused attention by using knowledgeable decision making, positive work effort leading to a solid commitment projected ahead, active role control, and near future deceleration and disengagement. For example, an employee prepares for retirement by revaluating what their job means to them. At career twilight more employees look for what information about what it is to be retired when they leave work, take on activities that will be useful at retirement, play a major role in taking strategic decisions, i.e. succession plan, expansion creating value in their organisations, gradually scale down their own activities, seeing themselves as valuable and prepares to leave a legacy sound job performance behind. Whether successful or not this pattern of adaptation influence employees job performance.

\subsection{Empirical review}

Literature examining about to retire and ageing workers job satisfaction have identified that older workers continue to work because of financial reasons and the values place 
on work itself, and personal belief about work (Higgs et al., 2003). Paynter (2004) assessment of the motivational profiles of teachers showed that teachers above 50 years have significantly higher motivation scores than younger teachers below 40 years. Lange et al. (2006) found that age differences did not influence the level of work satisfaction but general value or similar aspects of work. Blau (2000) and Otto et al. (2010) found that job satisfaction predicted occupational change readiness for apprentices who are approaching the transition to their main occupation as unsatisfied apprentice scored higher on occupational change readiness. Lord (2002) demonstrated that self-esteem needs and self-actualisation were important motivation for older worker with sufficient income to retire. Jepsen and Choudhuri (2001) found that employees with stable occupational career patterns (OCPs) experienced lower job satisfaction than those who changed career patterns. Wanberg (1995) found that employees who transited from a demotivated activity where happier with their present jobs as reactions was stimulated by personal characteristics and factors around the change context (Wanberg \& Banas, 2000).

\section{Method}

\subsection{Research design}

The study was quantitative study which adopted cross-sectional survey research design in collecting the data.

\subsection{Study sample}

The population of the study includes employees close to their retirement either by age or due to years of service in ministries and parastatals in Lagos State, Nigeria. The respondents were selected from the population of about to retire civil servants from six ministries which include ministries of Health, Education, Sports and Culture, Agriculture, Finance, Works and Housing. One hundred and seventy-five employees close to retirement in six selected ministries chosen as the representative sample were selected through a multi-stage sampling method. At the first stage, purposive sampling technique adopted selected ministries. Consecutive sampling was used to select employees close to retirement who have three years or less to spend in service from the selected ministries within the period under consideration (July - August, 2015).

\subsection{Instrument}

The items on the questionnaire will be adapted from previous validated studies. The instrument asked questions the socio-demographic characteristics of the participants. These include: age, sex, education qualification, year of experience, income, marital status and educational qualification. Career transition was measured using career transitions inventory (CTI). The CTI originally had six constructs: (a) self-efficacy, (b) self-versus-relational focus, (c) motivation, (d) rational beliefs, (e) risk-taking, and (f) control. Reliability of the sub-dimensions ranged from .66 to .87 (median .69). The subscales of the CTI were positively correlated with the scales from the My Vocational Situation and the Hope Scale assessments (Heppner, Multon \& Johnston, 1994). Self-esteem was measured using self-esteem scale 10- item scale developed by Rosenberg's (1965). Sample items include: I feel that I am person of worth, comparable to others; I feel confident at any times. The scoring format was anchored on a5-point Likert scale ranging from $1=$ strongly agree to $5=$ strongly disagree. The reliability of the scale as reported by the author is 0.82. Items 2, 5, 6, 8 and 9 had to be reversed. Higher scores indicate a higher global self-esteem. Self-efficacy was measured using Judge et al., (1998) 8-item measure self-efficacy scale. The measure includes: I often feel that there is nothing that I cannot do very well. The scale was anchored on a 5-point scale likert response format ranged from 1 (strongly disagree) to 5 (strongly 
agree). The items within each scale were averaged to form a single score for generalized selfefficacy. Judge et al. (1998) reported o.88 alpha as reliability for the scale. High scores on the scale represent increasing confidence and self-directed behaviour among the employees. Job satisfaction was captured using items adapted from the short form 20-item Minnesota satisfaction scale developed by Weiss, Dawis, England and Lofquist (1967). The scale is made up of two dimensions: intrinsic or extrinsic satisfaction. Responses was scored on a likert format ranged 1 (strongly disagree) to 5 (strongly agree). Reliability for the intrinsic scale was reported to be .86: .80 for the extrinsic subscale, and .90 for the overall satisfaction scale.

\subsection{Procedure for data collection}

The researcher sought the necessary approval from the head of service. The researcher personally administer the questionnaires to the employees close to retirement at their various offices. The researcher obtained a verbal consent from the respondent after explaining to the respondents the nature of the research and that the information would be treated with confidentially. The questionnaires were administered directly on participants, while some was retrieved immediately and other respondents requested for the completion of the questionnaire. Three hundred and sixty questionnaires were distributed however only one hundred and seventyeight were retrieved. The well completed questionnaires were used in the data analysis.

\subsection{Method of data}

Data analysis was carried out with the aid of Statistical Package for Social Sciences (SPSS) version 20. Descriptive statistics (frequency count, mean and standard deviation) is used to offer a snapshot of the basic characteristics of the respondents' demographics. Relationship between variables were tested using Pearson correlation analysis at 0.05 level of significance.

\section{Results}

Frequency count and percentage were used to analyse respondents' demographic information (age, gender, educational qualification, designation and length of service). The analyses are summarised below.

Table 1. Socio demographic characteristics of respondents

\begin{tabular}{llcc}
\hline Demographic Characteristics & Category & Frequency & Percentage \% \\
\hline Gender & Male & 103 & 58.9 \\
Age & Female & 72 & 41.1 \\
& Below 50 & 43 & 24.6 \\
Marital Status & $50-55$ & 65 & 37.1 \\
& $56-60$ & 67 & 38.3 \\
& Married & 153 & 87.4 \\
Religion & Single & 11 & 6.3 \\
& Divorced & 5 & 2.9 \\
\multirow{4}{*}{ Educational Qualification } & Widowed & 6 & 3.4 \\
& Christianity & 108 & 61.7 \\
& Islam & 65 & 37.1 \\
& Others & 2 & 1.1 \\
& O' Level & 51 & 29.1 \\
& OND/NCE & 29 & 16.6 \\
& HND & 18 & 10.3 \\
& BSC/BA/BED/BENG & 31 & 17.7
\end{tabular}


A. A. Olusola \& A. A. Ishola - Correlates of Job Satisfaction Among Civil Servants ...

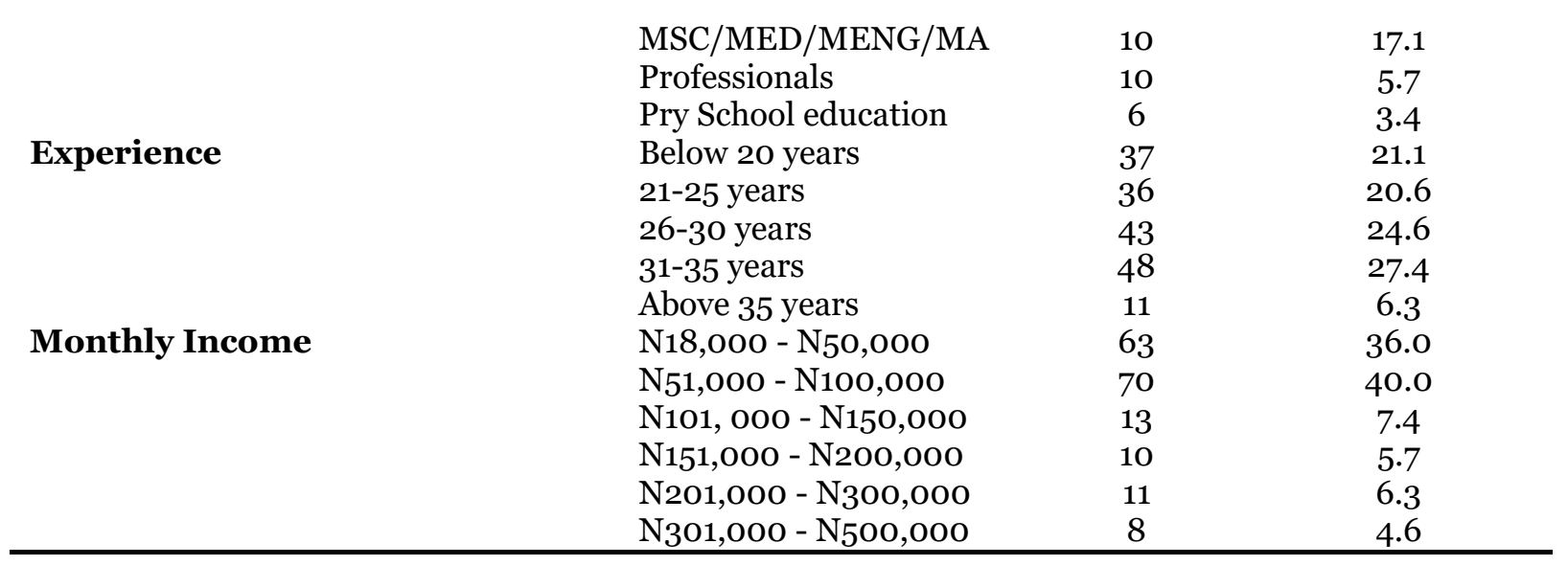

Results revealed that cumulative $75.4 \%$ were above 50 years of age which shows that the larger percentage are close to retirement either by age or years in service, while only $24.1 \%$ were below 50 years of age and are closer to retirement due to years spent in the civil service. As stipulated retirement in the Nigeria civil service is 60 years or 35 years in service. 87.4\% were married. The larger percentage of the respondents (61.7\%) were Christian. Distribution based on highest educational attainment shows that the respondents had primary school (3.4\%), secondary school (29.1\%), OND/NCE (16.6\%), HND (10.3\%), postgraduate degrees (17.1\%), and professionals (5.7\%) certification. Cumulatively, $66.3 \%$ have 30 years or less years of experience, 27.4\% have 31-35 years of experience, while 6.3\% have years of experience above 35 years. This shows the some of the workers have their services extended beyond retirement age or years of experience. Furthermore, the result reveals that $76 \%$ earned $=\mathrm{N}=100$, o00 or less showing a high preponderance of lower cadre employees in the present sample.

Correlation analyses of all the study variable was done using Statistical Package for Social Sciences (SPSS), the resulting output generated and arranged in Table 2.

Table 2. Mean, standard deviation and zero order correlation matrix showing the relationship among variables in the study.

\begin{tabular}{lccccccccc}
\hline Variables & Mean & SD & 1 & 2 & 3 & 4 & 5 & 6 & 7 \\
\hline JSAT & 85.73 & 13.73 & & & & & & & \\
PCTR & 51.61 & 6011 & $.55^{* *}$ & 1 & & & & & \\
PCCD & 36.97 & 7.60 & -.07 & - & 1 & & & & \\
PCC & 22.15 & 5.81 & $-.26^{* *}$ & 0.85 & - & 1 & & & \\
PCS & 17.34 & 4.48 & $-.29^{* *}$ & -.13 & $.62^{* *}$ & - & 1 & & \\
PCD & 18.31 & 5.53 & $-.19^{*}$ & $-.35^{* *}$ & $.61^{* *}$ & $.25^{* *}$ & - & 1 & \\
SE & 26.93 & 3.57 & $.53^{* *}$ & $-.28^{* *}$ & $.40^{* *}$ & .12 & $.34^{* *}$ & - & \\
GSE & 43.21 & 6.68 & $.75^{* *}$ & $.56^{* *}$ & $-.39^{* *}$ & -.03 & $-.29^{* *}$ & $-.45^{* *}$ & - \\
\hline
\end{tabular}

${ }^{* *}$ Correlation is significant $(\mathrm{p}<0.01)$, Correlation is significant $(\mathrm{p}<0.05),{ }^{*},-$

JSAT: Job satisfaction; PCTR: Personal Career Transition readiness; PCCD: Personal Career Confidence Development; PCC: Personal Career Control; PCS; Personal Career Support; PCD:

Personal Career Decision; SE: Self Esteem; GSE: General Self Efficacy

The results demonstrated that Career Transition readiness $(\mathrm{r}=.55, \mathrm{p}<0.01)$, selfesteem $(\mathrm{r}=.53, p<0.01)$, and general self-efficacy $(\mathrm{r}=.76, \mathrm{p}<0.01)$ were significant positive correlates of job satisfaction. It was demonstrated that high self-value, self-confidences induced higher levels of job satisfaction in about to retire workers. In addition, being read to make career transition was associated with high job satisfaction. It is increasingly clear that people who are confident of the future, valued their career or contributions to the organisation and are readily prepared to other career roles in life were more satisfy with their jobs. However, the result demonstrated that personal career control $(\mathrm{r}=-.26, \mathrm{p}<0.01)$, career support $(\mathrm{r}=-.17, \mathrm{p}<0.01)$, and 
personal career decision $(\mathrm{r}=-.19, \mathrm{p}<0.01)$ have significant inverse relationship with job satisfaction. This implies that though individuals received low support for their career, were not responsible for their career decisions and control; they were still happier with their jobs. This suggest that possibly the presence high self-esteem and self-efficacy moderated the job satisfaction outcome for career transition variables.

\section{Discussion}

The study investigated relationship between job satisfaction and career transition variables among employees close to retirement in Lagos state public service. The results demonstrated that career transition readiness, self-esteem, and general self-efficacy were significant positive correlates of job satisfaction. High self-value, self-confidences induced higher levels of job satisfaction among employees close to retirement. In addition, readiness to make career transition was associated with higher job satisfaction. These findings support Lord (2002) who found that self-esteem needs and self-actualisation are primarily motivation for older worker with sufficient income to retire. As demonstrated, employees being confident of the future, valuing their career or contributions to the organisation and are readily prepared to other career roles in life will be more satisfy with his/her jobs. In the same vein, the findings support the study which identified job satisfaction proved to be correlates of occupational change readiness for apprentices who are approaching the transition to their main occupation (Blau, 2000; Otto et al., 2010). Those unsatisfied with their job or apprenticeship scored higher on occupational change readiness. These findings is similar to Higgs et al. (2002) who demonstrated that older employees who valued their job or their personal belief were happier with their job and see reason to continue on their jobs. In addition, the result demonstrated that personal career control, career support, and personal career decision have significant inverse relationship with job satisfaction. This implies that though individuals received low support for their career transition effort, career decisions and control; they were still happier with their jobs. Inadequate preparation and lack of support did not dampen their level of job satisfaction (Baumgardner, Heppner \& Arkin, 1986). The findings were in contrast with Jepsen and Choudhuri (2001) who demonstrated that employees with stable occupational career patterns (OCPs) often experienced lower job satisfaction than those who changed career patterns. Results also support Wanberg (1995) who demonstrated that employees who transited from a demotivated activity where happier with their present jobs as reactions was stimulated by personal characteristics and factors around the change context (Wanberg \& Banas, 2000). This finding support Locke's (1976) range of affect theory and super career construction theory that employees'value expectation at any point in their career affects their job related attitude. In addition, situation during career transition shapes employees job related attitude. Inadequate attention to civil servant and their needs make them dissatisfied with their job. These have overall impact on the productivity and commitment of these employees at these point in time.

\section{Conclusion and recommendation}

This study reveals that most of the career transition and self-concept variables used in the study are covariates of job satisfaction among employees close to retirement in the Lagos State public service with the exception of personal career confidence development.This study concluded that career transition readiness and high employees self-values are factors that is making civil servants happy on the job. In addition, the result demonstrated lack of control over their career, lack of support for their career and poor career decision were associated with job dissatisfaction. In other words, individual self-concept is what is making the job meaningful, despite lack of support for civil servant at the twilight of their career. This study recommends job enrichment, retirement planning and career counselling for the ageing work force. This study is limited due to its cross-sectional nature and small sample size. It is recommended that future study should be 
longitudinal, the sample size should be increased to include public servants in parastatals and agencies. In addition, future studies should examine the possible presence of mediational and moderation effect of self-esteem and self-efficacy on career transition variables and job satisfaction.

\section{Declaration of interest}

We declare that:

- We have no conflict of interest

- We have a competing interest

This statement is to certify that all authors have seen and approved the manuscript being submitted. We warrant that the article is the authors' original work. We warrant that the article has not received prior publication and is not under consideration for publication elsewhere. On behalf of all co-author, the corresponding author shall bear full responsibility for the submission. This research has not been submitted for publication nor has it been published in whole or in part elsewhere. We attest to the fact that all authors listed on the title page have contributed significantly to the work, have read the manuscript, attest to the validity and legitimacy of the data and its interpretation, and agree to its submission to the Open Journal for Psychological Research (OJPR).

\section{References}

Blau, G. (2000). Job, organizational, and professional context antecedents as predictors of intent for inter role work transitions. Journal of Vocational Behaviour, 56(3), 330-345. http://doi.org/10.1006/jvbe.1999.1718

Burke, R. J., Burgess, Z., \& Fallon, B. (2006). Organizational practices supporting women and their satisfaction and well-being. Women in Management Review, 21(5), 416-425. http://doi.org/10.1108/09649420610676217

Daft, R., \& Marcic, D. (2001) Understanding management. Boston: South-western Thomson Learning.

Davies, E. M. M., Van der Heijden, B. I. J. M., \& Flynn, M. (2017). Job satisfaction, retirement attitude and intended retirement age: A conditional process analysis across workers' level of household income. Frontier of Psychology, 8, 891. http://doi.org/10.3389/fpsyg.2017.00891

Drabe, D., Hauff, S., \& Richter, N. F. (2014). Job satisfaction in aging workforces: an analysis of the USA, Japan and Germany. The International Journal of Human Resource Management, 26(6), 783805. http://doi.org/10.1080/09585192.2014.939101

Guglielmi, D., Avanzi, L., Chiesa, R., Mariani, M. G., Bruni, I., \& Depolo, M. (2016). Positive aging in demanding workplaces: The gain cycle between job satisfaction and work engagement. Frontier Psychology, 7, 1224. http://dx.doi.org/10.3389/fpsyg.2016.0122

Hannes Zacher, Cort W. R. (2017) Change in job satisfaction negatively predicts change in retirement intentions. Work, Aging and Retirement, 3(3), 284-297. http://doi.org/10.1093/workar/waxoo9

Heppner, M. J., Fuller, B. E., \& Multon, K. D. (1998). Adults in involuntary career transition: an analysis of the relationship between the psychological and career domains. Journal of Career Assessment, 6(3), 329-346. http://doi.org/10.1177/106907279800600304 
Heppner, P.P., Baumgardner, A.H. \& Arkin, R.M. (1986). Role of causal attribution in personal problem solving. Journal of Personality and Social Psychology, 50(3), 636-643. http://doi.org/10.1016/0022-1031(75)90046-3

Higgs, P., Mein, G., Ferrie, J., Hyde, M. \& Nazroo, J. (2003). Pathways to early retirement: structure and agency in decision-making among British civil servants, Ageing \& Society, 23(6), 761-778.

Jepsen, D. A., \& Choudhuri, E. (2001). Stability and change in 25-year occupational career patterns. The Career Development Quarterly, 5o(1), 3-19. http://doi.org/10.1002/j.21610045.2001.tboo884.x

Judge, T. A., Locke, E. A., Durham, C. C., \& Kluger, A. N. (1998). Dispositional effects on job and life satisfaction: The role of core evaluations. Journal of Applied Psychology, 83, 17-34. http://doi.org/10.1097/00126450-200507000-00011

Lang, F. R. \& Carstensen, L.L. (2002). Time counts: Future time perspective, goals, and social relationships. Psychology \& Aging, 17(1), 125-40. http://doi.org/10.1037/0882-7974.17.1.125

Lange, A. H. de Taris, T. W., Jansen, P. G. W., Smulders, P., Houtman, I. L. D., \& Kompier, M. A. J. (2006). Age as a factor in the relation between work and mental health: Results from the longitudinal TAS study. In: J. Houdmont and S. McIntyre (Eds.), Occupational health psychology: European perspectives on research, education and practice (Vol. 1) (pp. 21-45). ISMAI Publications, Maia, Portugal.

Locke, E. A. (1969). What is job satisfaction? Organizational Behaviour and Human Performance, 4(4), 309-336. http://doi.org/10.1016/0030-5073(69)90013-0

Locke, E. A. (1976). The nature and causes of job satisfaction. Handbook of industrial and organizational psychology. Chicago: Rand McNally, 1319-1328.

Lord, R.L. (2002), Traditional motivation theories and older engineers. Engineering Management Journal, 14(3), 3-7. http://doi.org/10.1080/10429247.2002.11415167

Lord, R. L. (2004). Empirical evaluation of classical behavioural theories with respect to the motivation of older knowledge workers, dissertation. University of Alabama, Tuscaloosa, AL.

Mega, F. F., Ely, S., Elfia, N., Lohana, J., \& Syihabudhin, (2018). The effect of self efficacy and self-esteem towards the Pt Garuda Food Indonesia employee's job satisfaction. In: The First International Research Conference on Economics and Business (79-90). KnE Social Sciences \& Humanities. http://doi.org/10.18502/kss.v3i3.1875

Mukhtar, F. (2012). Work life balance and job satisfaction among faculty at Iowa State University. Graduate Theses and Dissertations. http://lib.dr.iastate.edu/etd/12791

Otto, K., Dette-Hagenmeyer, D. E., \& Dalbert, C. (2010). Occupational mobility in members of the labor force: Explaining the willingness to change occupations. Journal of Career Development, 36, 262-288. http://doi.org/10.1177/0894845309345842

Paynter, J. L. (2004). The motivational profiles of teachers: Teachers' preferences for extrinsic, intrinsic, and moral motivators, dissertation. Baltimore, MD: The John Hopkins University.

Robertson, H. C. (2010). Life satisfaction among midlife career changers: A study of military members transitioning to teaching, published PhD dissertation. Virginia Polytechnic Institute and State University, Virginia.

Robertson, H. C., \& Brott, P. E. (2014). Military veterans' midlife career transition and life satisfaction. The Professional Counselor, 4, 139-149. http://doi.org/10.15241/hcr.4.2.139

Rosenberg, M. (1965). Society and the adolescent self-image. Princeton, NJ: Princeton University Press.

Stone, R. (2005). Human resource management. Sidney, Australia: John Wiley and Sons, Ltd.

Suldo, S. M., \& Huebner, E. S. (2006). Is extremely high life satisfaction during adolescence advantageous? Social Indicators Research, 78(2), 179-203. http://doi.org/10.1007/s11205$\underline{005-8208-2}$ 
A. A. Olusola \& A. A. Ishola - Correlates of Job Satisfaction Among Civil Servants ...

Szinovacz, M. E. (2003). Contexts and pathways: Retirement as institution, process, and experience. In: G. A. Adams \& T. A. Beehr (Eds.), Retirement: Reasons, processes, and results (pp. 6-52). New York: Springer Publishing Company. University Microfilms International.

Wanberg, C. R., \& Banas, J. T. (2000). Predictors and outcomes of openness to changes in a reorganizing workplace. Journal of Applied Psychology, 85(1), 132-142. http://doi.org/10.1037/00219010.85.1.132

Wanberg, C.R. (1995). A longitudinal study of the effects of unemployment and quality of reemployment. Journal of Vocational Behavior, 46(1), 40-54. http://doi.org/10.1006/jvbe.1995.1003

Weiss, D. J., Dawis, R. V. England, G. W. \& Lofquist, L. H. (1967). Manual for the Minnesota Satisfaction Questionnaire. Vol. 22, Minnesota Studies in Vocational Rehabilitation, Minneapolis: University of Minnesota, Industrial Relations Center.

Weiss, H. M. (2002). Deconstructing job satisfaction: Separating evaluations, beliefs and affective experiences. Human Resource Management Review, 2(2), 173-194. http://doi.org/10.1016/S1053-4822(02)00045-1

Wikispaces.psu.edu (2016). PSYCH 484: Work attitudes and job motivation. Retrieved 22 December 2016, from https://wikispaces.psu.edu/collector/pages.action?key=PSYCH484 